Article

\title{
Growing for Sydney: Exploring the Urban Food System through Farmers' Social Networks
}

\author{
Jessica Ann Diehl 1 \\ School of Design and Environment, National University of Singapore, Singapore 117566, Singapore; \\ akijac@nus.edu.sg
}

Received: 22 February 2020; Accepted: 15 April 2020; Published: 20 April 2020

\begin{abstract}
Growing urban populations' increased demand for food coupled with the inherent risks of relying on the global food system has spurred planning strategies by city governments for implementing urban agriculture at different scales. Urban agriculture manifests in a variety of different forms, often with different functions. However, within each type, embeddedness in the socio-ecological urban system can vary substantially as a result of specific characteristics and actors involved. This has a profound impact on the feasibility and sustainability of individual farm practices and, consequently, when scaled up to the urban food system as a whole. In this paper, I apply the concept of social networks to understand how commercial urban farmers gain access to and make use of tangible and intangible resources available to them in the context of the urban food system. Using a qualitative approach, semi-structured interviews were conducted with 15 farmers in Sydney, Australia. The question guide, developed based on the Sustainable Livelihoods Framework, captured farm traits and access to resources through social networks. Findings illustrate three emergent patterns leveraging urban-local, rural-local, and urban-global networks as farmers pursued sustainable livelihoods. In conclusion, land is only one driver, among many, of the sustainability of the local food system.
\end{abstract}

Keywords: urban agriculture; social networks; qualitative interviews; Sustainable Livelihoods Framework; urban food system; Sydney; Australia

\section{Introduction}

The trend of cities worldwide experiencing population growth is development encroaching peri-urban and rural edges. The existential dilemma of prioritizing land use for people to live, work, play, and eat is causing, often irreversible, changes to landscapes, and mirrors changing values of how land should be used-farmland increasingly replaced by residential and commercial uses. With growing urban populations' rising demand for food coupled with the inherent risks of relying on the global food system, many city governments are developing planning strategies for implementing urban agriculture at different scales [1]. Manifesting in a variety of forms, often with different functions, urban agriculture has the potential to contribute more than just food for urban residents, but also aims to meet different social, economic, and environmental needs. Different types of urban agriculture are typically grouped by trait (e.g., community gardens, urban farms, edible school gardens, and rooftop hydroponic systems); however, within each type, embeddedness in the socio-ecological urban system can vary substantially as a result of specific characteristics and actors involved. This has a profound impact on the feasibility and sustainability of individual farm practices and, consequently, when scaled up to the urban food system as a whole. Using the concept of the urban food system, this paper contributes empirical, qualitative research on urban farmers' access to resources through social networks in the context of Sydney, Australia, to better understand potential drivers and constraints for sustaining and implementing commercial urban agriculture for a more resilient urban food system. 


\subsection{Urban Food System Concepts}

Broadly, the urban food system is comprised of the different modes of provisioning (production, processing, distribution, preparation and consumption, and waste) within a geographic footprint (local to global), dependent on resources (land, seeds, labor) and cultural conditions (actor health, consumer food preference) [2-4]. Béné et al. recently published a critical review of the state of the research related to food system drivers and proposed a conceptual framework (Figure 1) [3]. They highlighted that discourse around concepts and definitions of "food systems" increasingly emphasizes the dynamic nature underpinning the functioning of elements and activities which inherently drive sustainability and future food security [3]. Within the food system, production and supply is an essential point of origin for the functioning of the food system (food being the essential item) [4]; key drivers include technology and intensification, climate change and environmental degradation, and policy and infrastructure. As growing populations in urban areas demand greater food supplies, coupled with a rise in rural to urban migration and the need to create livelihood options, there has been an increase in urban agriculture worldwide $[5,6]$.

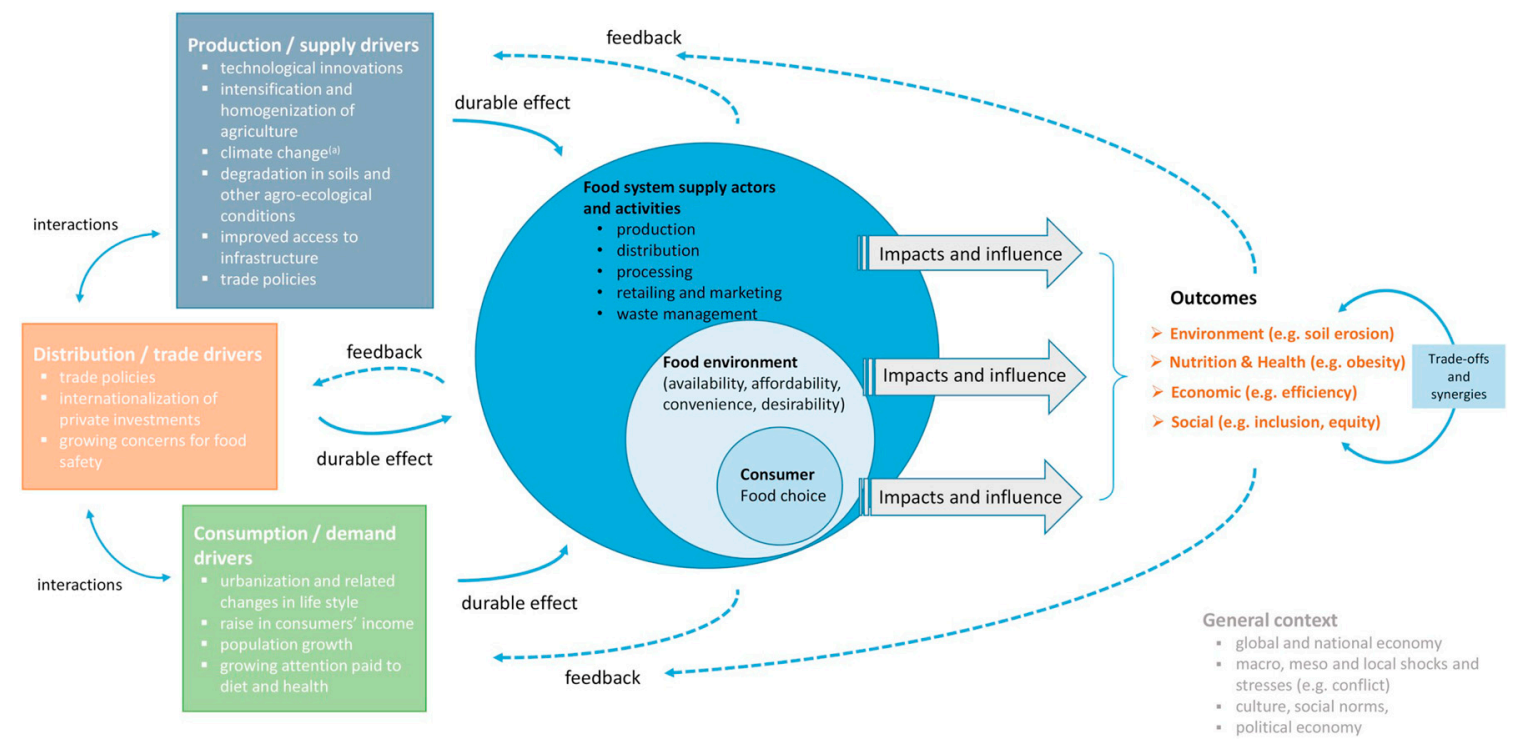

Figure 1. Conceptual framework of food systems with drivers developed by Béné et al. [3].

Urban and peri-urban agriculture is broadly defined as "an industry located within ('intra-urban') or on the fringe ('peri-urban') of a town, a city, or a metropolis, that grows and raises, processes and distributes a diversity of agricultural products from both plants and animals, using human, land and water resources, products, and services found in and around that urban area" [7]. Urban agriculture can be practiced in gardens, rooftops, empty public land, cellars, or field plots by urban residents from various backgrounds. The orientation and scale of such activities may vary from subsistence-oriented cultivation, to more recreational types of agriculture at the micro scale, through small-scale semi-commercial gardeners and livestock keepers, to medium- and large-scale commercial enterprises. Importantly, the distinguishing characteristic of urban agriculture is its embeddedness in the urban economic, social, and ecological system. Urban agriculture uses urban resources, e.g., land, labor, urban organic wastes, and water, produces for urban citizens, is strongly influenced by urban conditions, e.g., policies, land values, urban markets, and prices, and impacts the urban system by effecting urban food security and poverty, ecological, and health impacts [6,7]. The location of urban agriculture includes greenbelts, urban fringes, vacant or under-utilized city lots, community gardens, fish farms, and greenhouses [8]. The urban fringe is a uniquely dynamic location that generally moves further away from the urban core as the city grows outward, but it is always within the sphere of influence of the city. As roads and infrastructure are constructed to better link the urban core and 
urban fringe for commuting, land values tend to increase [8]. The urban fringe is where agriculture tends to intensify to take advantage of close proximity to urban markets, reliable water supply, and labor. However, the consequence is that agriculture on the urban fringe faces rising land values, land speculation by developers, and conflict with new residential owners over farm practices, e.g., farm odors and pesticide spraying.

It is a combination of proximity and embeddedness in the urban system (overlapping but distinct from the food system) that defines urban agriculture more than the specific form, function, or precise geography. As such, it is unrealistic to consider the practicalities and practice of urban agriculture independent from urban resources such as land and water availability, local market demand and pricing, or various other urban conditions or policies. If the systems that urban agriculture is embedded in are not sustainable, it is unlikely that urban agriculture is going to be sustainable. Therefore, it would be useful to understand the practice of urban agriculture and its outcomes as a livelihood pursuit by farmers who are embedded within a unique urban context. While there are diverse ways urban agriculture manifests, this research focuses specifically on commercial urban farming because of the potential to make a meaningful contribution to the food system and food security at the city-scale.

\subsection{Farmers and Livelihoods: Access to Resources}

Conceptualizing urban farming as embedded in the urban economic, social, and ecological systems suggests that a sustainable practice is more than simply connecting farms to consumers through short supply chains, but also connecting farms to all aspects of the urban food system to allow for adaptability to changes and increased resiliency. Ultimately, by definition, commercial farms are businesses that are intended to provide the farmer a sustainable livelihood. This research applied the Sustainable Livelihoods Framework (SLF) as a way of conceptualizing farmers' livelihood strategies within the urban food system.

The SLF, which evolved from the vulnerability-resiliency literature in response to rural development, was conceptualized as a framework for understanding the process of creating sustainable livelihoods (Figure 2) [9]. A livelihood is defined as "the capabilities, assets (including both material and social resources), and activities for a means of living. A livelihood is sustainable when it can cope with and recover from stresses and shocks, maintain or enhance its capabilities and assets, while not undermining the natural resource base" [10] (p. 5).

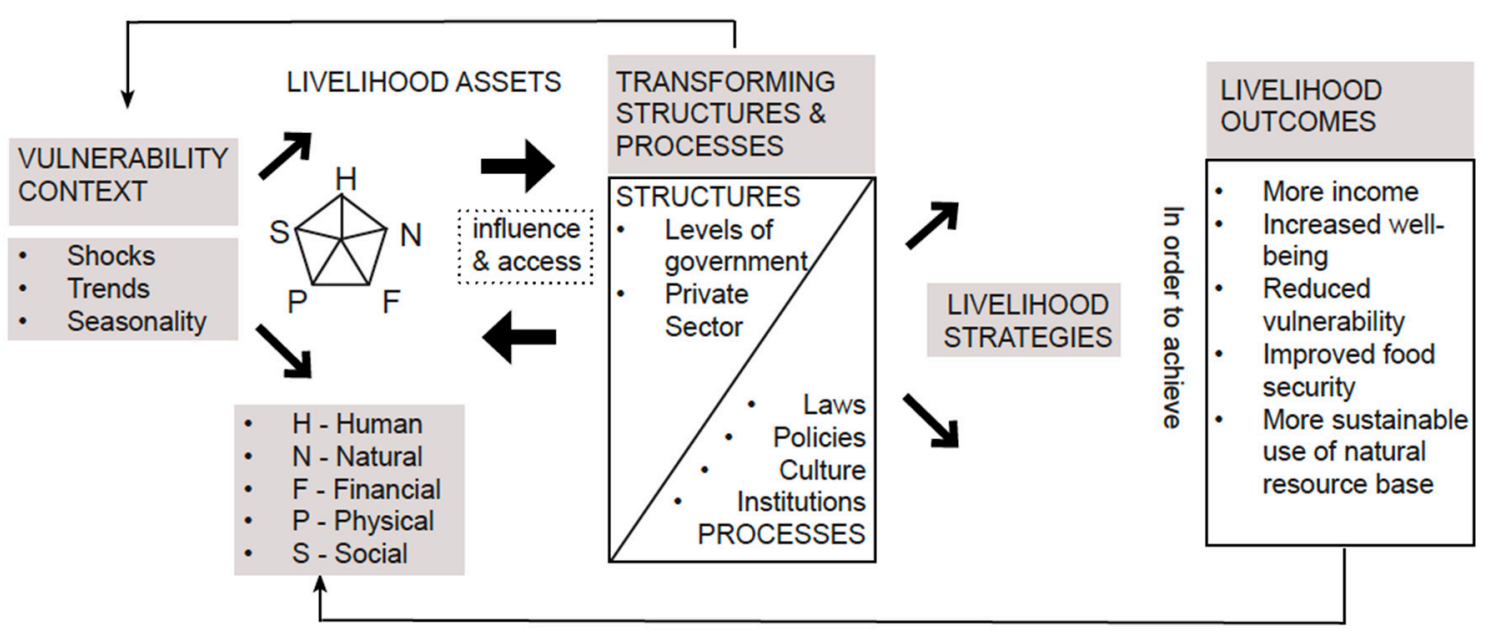

Figure 2. The Sustainable Livelihoods Framework by I. Scoones, adapted by D. Carney $[9,11]$.

The SLF focuses on people based on daily needs, acknowledging various capabilities rather than seeing social groups as homogenous [12]. It was developed to fill the need for a framework for bottom-up participatory approaches to community development, and was indebted to Amartya Sen's work on agency and capabilities [13]. In the SLF, livelihoods are defined as the assets (human, 
natural, financial, physical and social capital) and activities, as well as the ability to access assets and activities, that determine the living gained by an individual or household [14]. Livelihood strategies are influenced by the assets that are available to individuals or households; those with more assets have more options [15]. Hence, access to assets is a key element within the framework. To reduce vulnerability, it is necessary to increase access to resources [16]. However, it is not just the number of assets, but rather the quality and stability-and the ability to access them when needed. Although not explicit in the SLF, access to resources is influenced by social relations.

Social networks are a critical mechanism for mobilizing resources beyond the household $[16,17]$. Social networks are comprised of agents and the relationships between them [18]. Agents are defined as individuals or collectives, and relationships are defined as the contact, connection, or tie between a pair of agents. A core assumption of Social Network Analysis theory is that direct or intensive contact exposes agents to better information, greater awareness, and higher susceptibility to influence, whereas indirect contact exposes agents to new ideas, and potential access to useful resources, e.g., livelihood opportunities. Social networks act to channel information and resources to particular structural locations, help create interests and shared identities, and promote shared norms and values. The core theoretical problem in developing a methodology to measure a social network is to explain the occurrence of different relationships ("ties") between agents and account for variation in linkages. In overlapping the SLF and urban food system, it is useful to group agents based on their relative position across the modes of provisioning: production, distribution, consumption, etcetera. The assumption was that farmers influence and gain access to assets through social ties with different types of food system agents in an effort to create a sustainable livelihood. Understanding social ties individually and as a social network, with the farmer as the central agent, can bring to light where, how, and why commercial farming is a sustainable/unsustainable part of the urban food system.

\subsection{Sydney Food System and Urban Agriculture}

Like many high-income global cities, Sydney's government endeavors to develop policies that enable development of the peri-urban boundary of the city in order to meet the housing, employment, and practical needs of a growing population, while also aiming to protect and support local farmers-some multi-generational—that contribute to local food system stability [19]. The capital city of New South Wales, Sydney is currently the largest Australian city with a 2018 population of 4.79 million and an average growth rate of $1.3 \%$ (2000-2018) [20]. Located on the central east coast of Australia with a humid sub-tropical climate, Sydney is surrounded by peri-urban farmland that provides a buffer between the city and the Greater Blue Mountains World Heritage Area. There are an estimated 2000 vegetable growers, with more than $80 \%$ from non-Anglo cultural and linguistic backgrounds [21]. This diversity can be traced to a post-WWII wave of Southern European migrants who were encouraged to settle in new outer-suburban housing precincts in an urban planning effort to avoid slum creation. Migrants started market gardens on their plots of land as livelihood means when lacking language and other skills for employment elsewhere. At the time, land values were low at the peri-urban edge of the city, and farming enabled migrants to support their families and provide the city's markets with fresh food [22]. In subsequent decades, peri-urban agriculture has provided streams of migrants with the opportunity to participate in farming, the main groups from Lebanon, Malta, Vietnam, Cambodia, and China with rural backgrounds [21,23]. This history of agricultural pioneering evolved a strong link between peri-urban farmers and local markets [19]. The population of Sydney continued to grow, and by the 1980s, the peri-urban agricultural land surrounding the city was regarded by the government as land waiting for higher economic development-a perspective reflected by landowners and developers [24].

The peri-urban land that provided farmers access to urban markets, opportunity to tap in urban water infrastructure, and inexpensive land was also attractive to developers and those looking for more affordable living [21]. Farmers were increasingly displaced as the Sydney population spread out of the urban core. Figure 3 maps Sydney's urban growth history according to the NSW Metropolitan planning 
department, which illustrates corridors extending to the north-east and south-west of existing urban boundaries [25]. McFarland reported an estimate that growth corridors would consume approximately half the 2025 hectares currently under production for vegetable growing in the Sydney area, and that overall the greater Sydney region will lose about 6800 hectares of peri-urban land under Sydney 2036 [25]. As the city government focused on policies to support Sydney's position as a global city, and Australia's link to the global economy, the Western Suburbs emerged as greenfield housing developments for residents employed in the global market [22]. Thus, the city sprawled and shifted toward a more global economy, land values climbed, and the local market turned to cheaper food imports from overseas. Market factors have been a significant driver of the decline in urban and peri-urban farms related to cheaper imports from overseas and supermarkets sourcing from farmers who produce cheaper through economies of scale [19]. In an effort to remain competitive, farms have aggregated into larger farms, consequently becoming more reliant on irrigation, long distance transport, and central processing [8]. There is also the issue of the aging farmer population with children who are not interested in taking over the farm, and land holdings rezoned for residential use that offer a high re-sell value for retirement $[19,21]$.

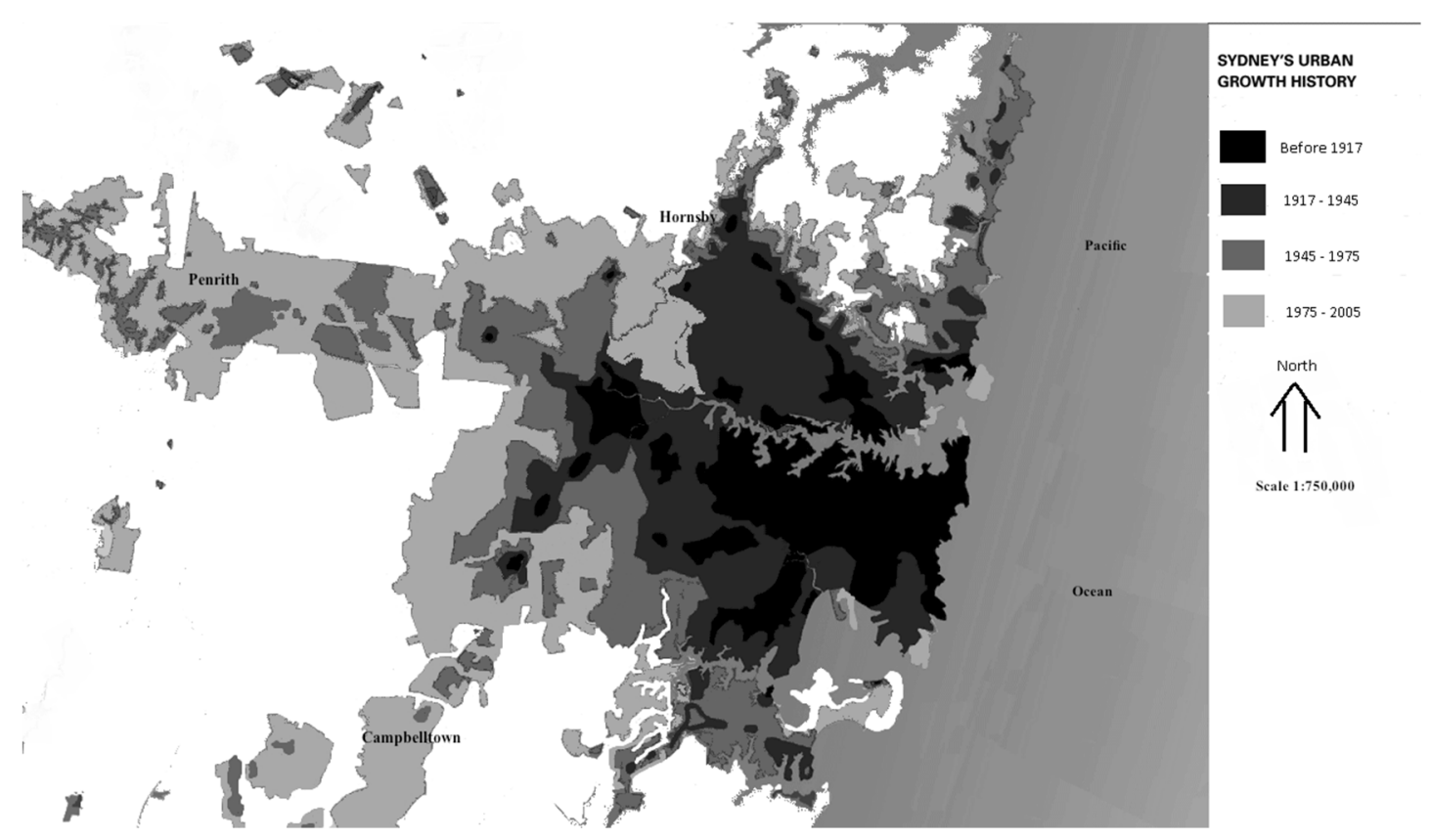

Figure 3. Sydney's urban growth history 1917-2005, adapted by P. McFarland from the NSW Department of Planning [26].

In this context of urbanization, it was dawning that loss of farms in the region was more than just a loss of locally grown product. Peri-urban agriculture has many important benefits, including a range of ecosystem services, short food transport miles that translate to reduced carbon emissions, and meeting consumer demand for more diverse local seasonal products [19]. Also, the 1998 Strategic Plan for Sustainable Agriculture-Sydney Region formally recognized that for agriculture to be sustainable in the Sydney region, it had to have community and political support [24]. In 2004 the Department of Infrastructure, Planning and Natural Resources released its Western Parklands Management Vision Summary Report. This was followed by the 2005 Metropolitan Strategy, which aimed to provide green space for new suburbs, called "Rural and Lifestyle Zones" (or "Green Zones"), in an effort to resolve the tension between urban development and farming in the Sydney Basin [22]. Specifically, the Metropolitan Strategy states that non-urban land will have greater recognition so it is not treated as land 'in-waiting' for development. However, there has been criticism from academia and the public 
that the Metropolitan Strategy prioritizes the private housing sector, with decisions being made based on land that is "best and highest use" with the greatest financial return [22].

This neo-liberal framing of land prioritizes the economic potential over cultural and environmental values. However, as peri-urban areas becoming more fragmented, multi-functionality is restricted. We have reached a post-productivist era in which there is broad evidence and awareness of our finite resources [25]. The case of Sydney's "Green Zones" is more than about the conflict between farmers and housing developments-it is about the changing urban food system from production to consumption and all the actors and processes that underlie this. Positively, there is growing support for locally produced food among Sydney residents; however, access to food and the sustainability of food chains requires a more comprehensive approach to understanding the urban food system [21]. But, it is not simply comparing "alternative" versus "mainstream" (also referred to as local/global) food systems-because they are fundamentally interconnected. Furthermore, in the context of Sydney, the spectrum of urban agriculture ranges across an ambiguous transect of rural to urban and supports social to community forms-from community gardens on one end to commercial, high-tech forms, such as the mushroom industry, on the other, and cottage industries, niche production, and market gardens filling the middle [24].

Local production is an important component of the current and future sustainability of Sydney's urban food system. Currently, the pressures on land used for agriculture come from a continuing trend toward displacement of agricultural land for affordable housing, increased competition from cheaper imported food, and the increasingly globalized food network [8]. However, it is a combination of proximity to the urban market and embeddedness in urban economic, social, and ecological systems that have a profound impact on the sustainability of urban and peri-urban farms. The SLF provides a framework for conceptualizing the farmers' livelihood strategies within the urban food system, which are highly dependent on access to resources. Although not explicit in the SLF, access to resources is influenced by social relations. Given this, the aim of this research was to understand the sustainability of the urban food system in Sydney by investigating commercial urban farmers' access to resources through social networks. Objectives were to summarize farm traits, including form and function attributes, and to measure social networks of urban farmers. Findings shed light on a diverse system of actors directly and indirectly involved in the local urban food system in Sydney. Three patterns emerged: farms located in the urban context and embedded in the local system, farms located in the urban context and embedded in both the local and global system, and farms located outside the urban boundary but embedded in the local (urban) system. Two additional cases of urban food system agents are described. The main conclusion is that land is only one driver, among many, of the sustainability of the local food system. Social networks enabling exchanges of information and resources among farmers, as well as strong connections between farmers and customers beyond financial transaction, are key characteristics underpinning the sustainability of the Sydney local food system. This study is particularly relevant in the context of a global trend of city governments developing planning strategies for implementing urban agriculture at different scales in response to urbanizing peri-urban lands.

\section{Materials and Methods}

This research employed a qualitative research design to measure commercial farmers' access to resources through social networks within the context of the urban food system in Sydney. Data were collected through key informant meetings, interviews, field observation, photography, memoing, cognitive mapping, and mapping using geographic information systems (GIS). Semi-structured interviews were conducted with local Sydney farmers. The interview question guide captured farm traits and access to resources through social networks. Research was approved by the National University of Singapore (NUS) Institutional Review Board as part of a larger research project to understand urban agriculture as an embedded practice in major urban centers in southeast Asia and Australia. This paper reports on findings from Sydney. 


\subsection{Sample and Sampling Procedure}

A preliminary site visit in July 2018 concluded that there were few commercial farms within the Sydney municipal boundary. It was observed, however, that local farmers' markets were highly active in Sydney, selling products from farms located in urban Sydney and the peri-urban and rural fringe (Figure 4). Using the conceptualization of urban agriculture as an integral part of the urban economic, social, and ecological system, as compared to agriculture that is linked to the global food system, I created a roster of all farmers' markets within the Sydney city boundary and populated a list of farms selling products there. By limiting the list to primary producers of edible products up to and including the peri-urban edge of Sydney, all value-added and non-edible product businesses were excluded, reducing the list to 29 farms. A Googlemaps search for "farm" indicated nine additional farms in/near Sydney; however, none met the trifold criteria as being linked to Sydney ecologically, economically, and socially. Site visits and further investigation also resulted in exclusion of 11 farms from the population list for the same reasons. During visits to farmers' markets and recommendations during farmer interviews, six farms were added to the list that were not identified through online searches. The final list included 25 farms that were invited via email, Instagram, or in-person at a farmers' market to participate in interviews. The aim was to ensure variation within the sample. While there is no definite calculation to determine sample size for adequately representing the sample population in qualitative research studies, the rule is to include enough people to reach a saturation point where little to no new information is generated, also called "sufficient redundancy" [27,28]. Research by Guest et al. [29] suggests that approximately twelve interviews should be sufficient to achieve saturation when researching a relatively homogeneous group (such as in this case of commercial urban farmers selling at Sydney farmers' markets).

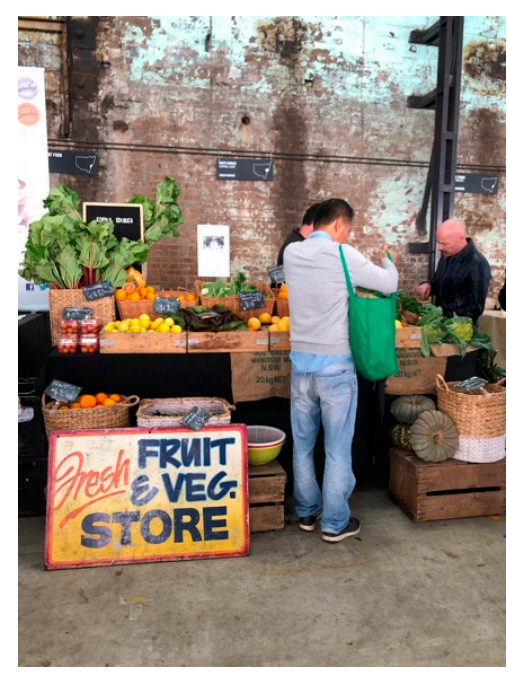

(a)

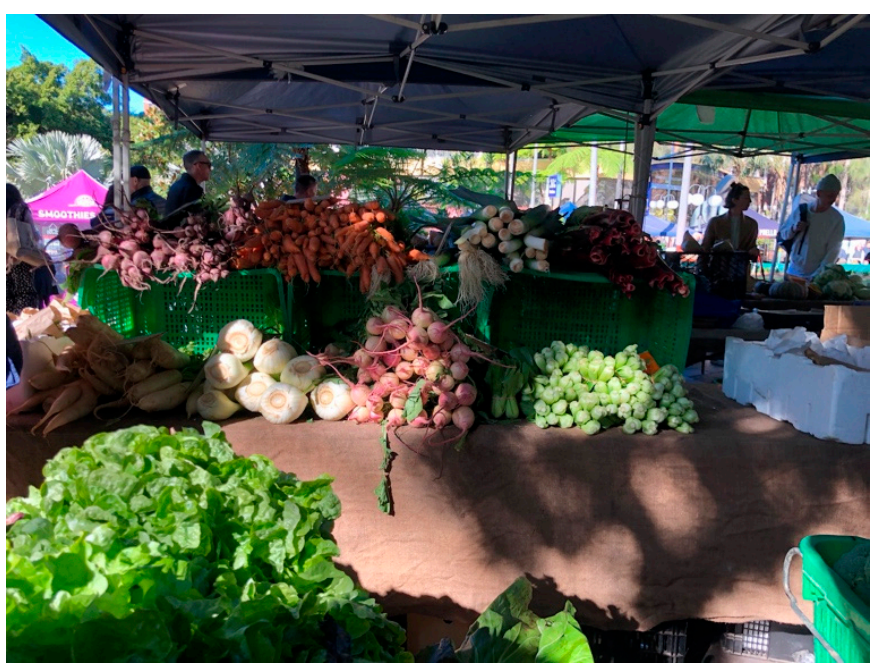

(b)

Figure 4. Sydney farmers' markets range from indoor to outdoor locations with a variety of local merchants ranging from farmers to artisans: (a) Carriageworks operates every Saturday and Sunday morning inside a renovated industrial building with 100+ local merchants; (b) King's Cross operates every Saturday and Sunday morning in a public park with $30+$ local merchants.

\subsection{Data Collection}

Semi-structured interviews were conducted either at the farm with a key representative (farmer or laborer) or at a farmers' market with the farmer, using an interview guide developed through prior fieldwork but modified for the local context [30]. The question guide was developed based on the Sustainable Livelihoods Framework (SLF) and social network theory to capture farm traits and access to resources through social networks. Beginning with a core set of questions, additional questions were 
introduced iteratively throughout fieldwork to reflect emerging themes and verify new information for subsequent interviews. This method of semi-structured interviewing allowed for collected data to be consistent across all interviews, while also providing flexibility for new topics to emerge [27]. During interview sessions, participants were asked to talk about farm characteristics and practices so that a detailed description of form and function could be recorded (farm size, types of crops grown, irrigation methods). This was followed by questions about social networks and access to resources. Interviewees were consented and the discussion was audio recorded (except in a few cases where recording was declined), as well as documented through extensive note-taking on an iPad by a research assistant.

In addition to interviews with farmers, data were also collected through field observation, memoing, and photography of farms (as permitted by farmers) and markets to document who was present, activities, types of crops and/or consumable products, and other agricultural-related characteristics. Memos were generated after each field day and as part of the analysis process. Memoing is a record of reflexive notes based on what the researcher is learning from in-coming data [27]. Memos can act as a first level of analysis and can be used to improve methods if data are thin or lacking. Observational data collection also provided a deeper understanding of farming practices and interactions both in the field and at local markets. Photography further added richness to the investigation with geo-referenced images that were linked geographically during analysis. Field observation, photography, and memoing occurred both concurrently and independently of interviews.

\subsection{Variables}

\subsubsection{Farm Traits: Form and Function}

Farm traits were operationalized as attributes of form and function. Using and expanding on the terms "form" and "function" from the literature, variables were defined to detail the varied aspects of production [31]. In the context of urban agriculture, the term "form" is used to identify the physical elements that comprise the landscape and the characteristics that define its physicality and visual character [32]. These include: location, proximity, land use zone, land title and tenure status, scale and intensity, technology, and materiality. The term "function" refers to activities and the purpose of those activities, as well as underlying systems and processes. These include: strategies, social integration, temporality, degree of profit orientation, product, water management, and multi-functional attributes [32-39]. While distinct, form and function are highly interrelated; a landscape's form can often dictate its function, and, likewise, the function a space serves will shape and drive its form [32].

To measure farm traits, farmers were asked about farm practices related to planting, irrigation, fertilizing, pest control, and harvesting. They were also asked to talk about tenure status, history, and future vision. Other traits were documented through observation and photography, including size, types of crops, and techniques. Each farm was characterized based on form and function to compare and contrast one from the other.

\subsubsection{Farm Social Networks: Access to Resources}

Social networks, comprised of individuals or collectives (agents) and the relationships between them [18], are a mechanism for channeling resources (tangible and intangible) to particular structural locations [17]. Within the context of this research, social networks translate as the relationship between farmers and other food system agents, grouped as collectives based on their relative position across the modes of provisioning, e.g., production (i.e., other farmers), distribution (i.e., vendors). Applying the SLF, a relationship is defined as the farmer's ability to access and influence livelihood assets through food system agents. Because it is not just the number of assets, but rather the quality and stability-and the ability to access them when needed-social relations, or the relationship between farmers and agents, can enable or create a barrier to resource access. In other words, social relations can facilitate or constrain. 
To measure social relations, I operationalized three core assumptions of social network theory (refer to Figure 5) [17]. The first assumption is that structural relations exist at specific time-place locales. Variables included where, when, and frequency of interactions with each social relation type. The second assumption is that the type of information exchanged (transaction) and degree of influence depends on whether the relation is direct or indirect. Variables included type of transaction, degree of influence, and direct/indirect relation. The type of transaction was defined in terms of livelihood assets comprised of five capitals: human capital, defined as knowledge and labor potential; natural capital, defined as ecosystem assets; financial capital, defined as money; physical capital, defined as tangible "things"; and social capital, defined as positive social connections (a subset of the overall social network, which can be comprised of positive or negative social connections). The degree of influence was defined as the ways in which social structures facilitate or constrain access. Degree of influence was measured as: investing, withdrawing, exchanging, and blocking. Investing was defined as a transaction that provided resources to an agent with the intention of getting something in return, withdrawing was defined as gaining resources, exchanging was defined as a transaction in which resources were both provided and gained, and blocking was defined as an agent preventing access to resources. Finally, direct relations were defined as bonding ties, a strong tie between immediate family members, neighbors, and friends, whereas indirect relations were defined as bridging ties, a connection with a person or people of different socioeconomic and/or cultural backgrounds [40]. The third core assumption of social network theory is that agents change relation structures both intentionally and unintentionally; structures are a micro to macro level process of within-group and across-group relations. Variables included a structural dimension defined as micro, meso, or macro. Micro structure was defined as the interactions between the farmer and family members, meso structure was defined as the interactions within the farming community, e.g., other farmers, hired laborers, and macro structure was defined as the interactions or connections with agents representing other components of the food system, including distributors, markets, customers, landlords, government officials, and others.

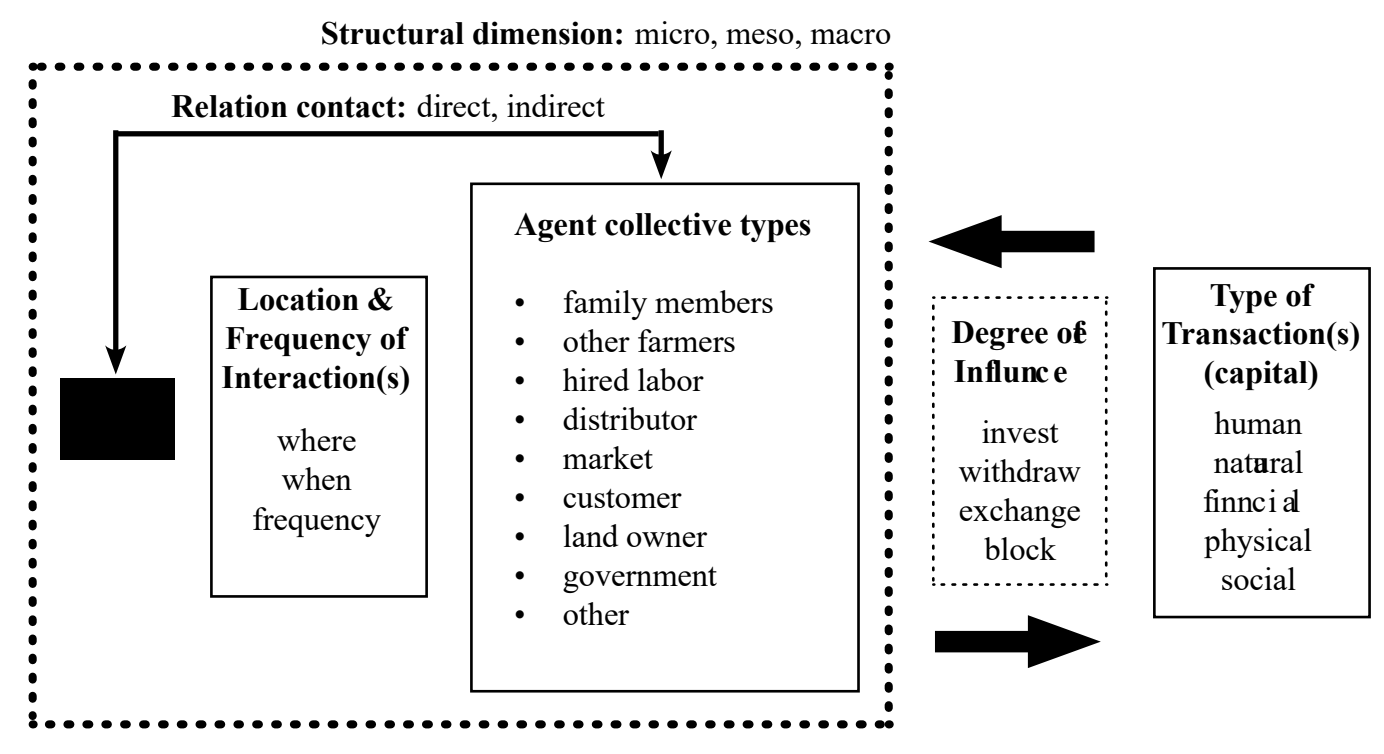

Figure 5. Diagram of social network variables.

In summary (Figure 5), social networks were measured using an ego-centric approach with the farmer as the central agent, and the tie to agents (collectives) across the food system was measured as the type of relationship, location and frequency of interaction, the type of transaction, the degree of influence, whether the relationship was direct or indirect, and micro to macro structural dimension. So, for example, one interview question was: How does your crop/product go from field/farm to consumer? Prompts were: Does a vendor come or do you take it to a market? Where? What is 
your relationship with the vendor? Do they give you a good price? How do you know what a good price is? Do they ever refuse to buy your produce/product? What do you do if that happens? Does (s)he give you advice regarding your farm? For example, suggest what to grow/raise? Does (s)he connect you with any people that might improve your farm? When do you receive payment for the harvest/product-in advance, on collection, after distribution? Is there any issue with this system? Notably, what happens if a crop fails or if you have surplus? Other interview questions followed this pattern, but were tailored to the agent collective type.

\subsection{Data Analysis}

Interviews, documented field observations, memos, and photographs were analyzed qualitatively. Audio recordings were transcribed, then cleaned and formatted using the interview guide as a template. Interviews, notes, memos, and photographs were imported into Atlas.ti version 8.4.4 for Mac (qualitative coding software) and coded. The first level of coding was completed by a research assistant to identify words and phrases related to demographic characteristics of the interviewee, form and function variables, and assigned agent collective types. Farm traits were output as an excel spreadsheet and summarized categorically to show distributions within the sample. The second level of coding qualified social ties related to location and frequency of interaction, type of transaction, degree of influence, whether the relationship was direct or indirect, and micro to macro structural dimension. Social tie results were grouped by agent collective type and exported as a word document for a third level of coding to summarize social networks by structural dimension (micro, meso, macro). Finally, data were analyzed to identify how social networks of the interviewed farmers provided access or constraints to livelihood assets. Results are reported as descriptive summaries.

\section{Results}

In total, 15 farms/farm-related actors participated in interviews over a two-week period in July 2019 (Figure 6). The participants included lead farmers, key decision-makers of the business, farm employees, and family members working full-time on the farm and/or involved with selling at the market. Eleven participants were lead farmers, one was a farming family-member, one was a farm laborer, one participant did not farm but provided farm inputs, and one participant processed products and sold as value-added goods. In addition to interviews with farmers, I visited ten farmers' markets, including Everleigh, EQ Market (twice), Bondi Beach, King's Cross, Carriageworks (twice), Orange Grove, North Sydney Produce Market, French's Forest, Manly, and Double Bay. Other site visits to local markets included Flemington Wholesale Market, Sydney Sustainable Market, and Paddy's Market. As a point of reference during the preliminary site visit, I documented 21 community gardens in Sydney on-the-ground.

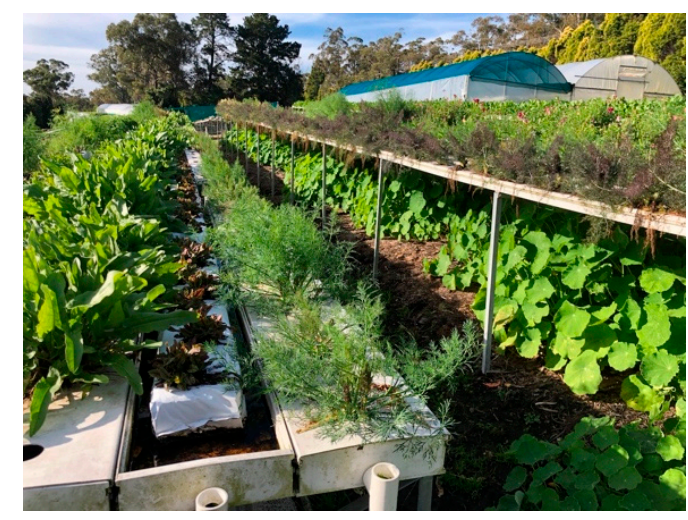

(a)

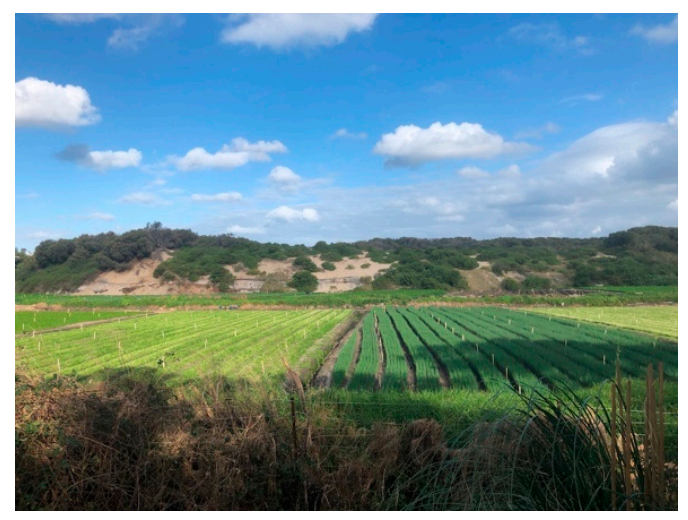

(b)

Figure 6. Cont. 


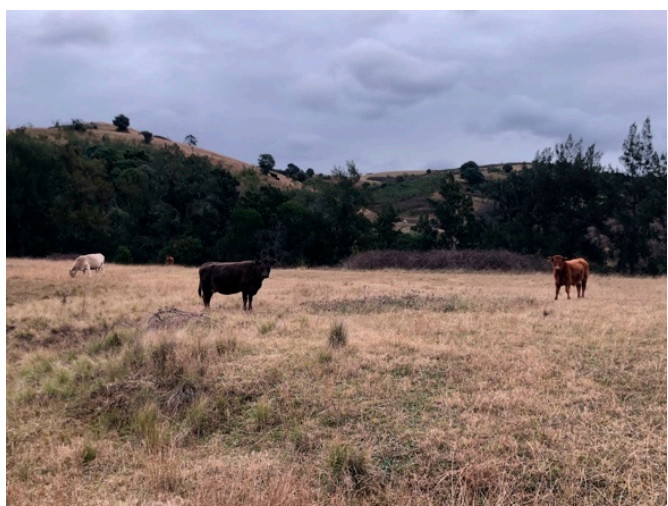

(c)

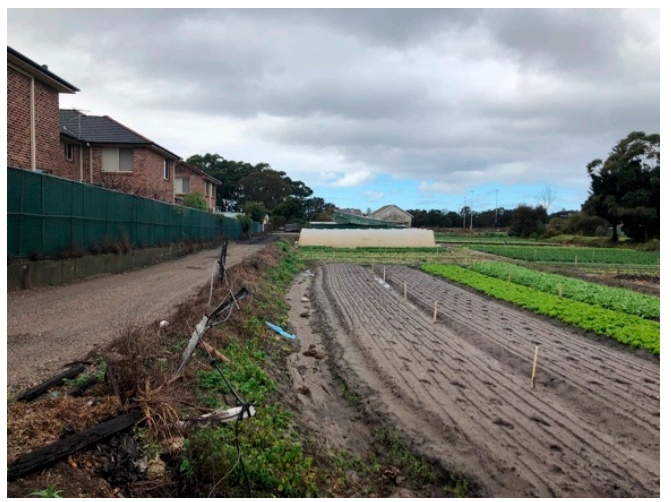

(d)

Figure 6. Images of diverse farms included in this study: (a) An agroecological farm incorporating raised bed hydroponics; (b) A conventional vegetable farm located in a floodplain; (c) An organic dairy farm; (d) Chinese heritage farm surrounded by residential development.

\subsection{Farm Traits: Form and Function}

This research focused on commercial urban farms, thus all farms were characterized as commercial (except for one managed by a city government agency that is planned to become commercial in the future) (refer to Table 1). All farms were formally registered (i.e., farmers owned or leased the land) and long-term or permanent enterprises-unsurprising that there was a lack of unregistered, informal commercial farm activity given the context of Sydney as a high-earning economy in a developed country. The majority of farms $(n=12 ; 80 \%)$ applied traditional systems (as opposed to high-tech) and had a low level of social integration (only the government-managed farm engaged community members). However, farm attributes varied for all other traits. Interviewees were diverse in age, education, citizenship, family history, product, and scale of operation. Many farmers were second- or third-generation immigrants from diverse places, including Hong Kong, China, Ireland, Mauritius, and Bangladesh, with farming a multi-generational family livelihood. In addition to commercial orientation, all farms provided multi-functional services to the urban system-including social activities ranging from cooking classes to filling a gap in migrant food demand.

Table 1. Farm traits based on form and function and farmer/interviewee demographics.

\begin{tabular}{ccc}
\hline Trait & Attributes $^{1}$ & Total $\boldsymbol{n} \mathbf{( \% )}$ \\
\hline Form & & \\
\hline \multirow{2}{*}{ Location } & Urban & $6(40 \%)$ \\
& Peri-urban & $6(40 \%)$ \\
\hline \multirow{2}{*}{ Proximity } & Rural & $3(20 \%)$ \\
\hline \multirow{2}{*}{ Land use zone } & On-plot & $9(60 \%)$ \\
& Neighborhood & $6(40 \%)$ \\
\hline \multirow{2}{*}{ Land title } & Agriculture & $10(67 \%)$ \\
& Other & $5(33 \%)$ \\
\hline Tenure status ${ }^{2}$ & Privately owned & $7(47 \%)$ \\
\hline
\end{tabular}


Table 1. Cont.

\begin{tabular}{|c|c|c|}
\hline Trait & Attributes ${ }^{1}$ & Total $n(\%)$ \\
\hline \multicolumn{3}{|l|}{ Form } \\
\hline \multirow{5}{*}{ Scale $^{3}$ and intensity } & small; single product & $1(7 \%)$ \\
\hline & small; diverse product & $2(13 \%)$ \\
\hline & medium; single product & $2(13 \%)$ \\
\hline & large; single product & $1(7 \%)$ \\
\hline & large; diverse product & $9(60 \%)$ \\
\hline \multirow{3}{*}{ Technology } & Traditional & $12(80 \%)$ \\
\hline & High-tech & $2(13 \%)$ \\
\hline & Mix trad. and high-tech & $1(7 \%)$ \\
\hline \multirow{2}{*}{ Materiality } & Vernacular & $11(73 \%)$ \\
\hline & Engineered/Designed & $4(27 \%)$ \\
\hline \multicolumn{3}{|l|}{ Function } \\
\hline \multirow{3}{*}{ Strategies } & Agro-ecology & $2(13 \%)$ \\
\hline & Organic & $6(40 \%)$ \\
\hline & Conventional & $7(47 \%)$ \\
\hline \multirow{2}{*}{ Social integration } & High & $1(7 \%)$ \\
\hline & Low & $14(93 \%)$ \\
\hline Temporality & Permanent, long-term & $15(100 \%)$ \\
\hline \multirow{2}{*}{$\begin{array}{c}\text { Degree of profit } \\
\text { orientation }\end{array}$} & Self-consumption ${ }^{4}$ & $1(7 \%)$ \\
\hline & Commercial & $14(93 \%)$ \\
\hline \multirow{3}{*}{ Product } & Vegetables & $11(73 \%)$ \\
\hline & Livestock & $3(20 \%)$ \\
\hline & Other & $1(7 \%)$ \\
\hline \multirow{4}{*}{$\begin{array}{c}\text { Water } \\
\text { management }\end{array}$} & Hydro/aquaponic & $1(7 \%)$ \\
\hline & Rain-fed; irrigated & $6(40 \%)$ \\
\hline & City water & $1(7 \%)$ \\
\hline & Unknown & $7(47 \%)$ \\
\hline Multi-functional & Varies & $\begin{array}{l}\text { Skills building, education, advocacy, agritourism, } \\
\text { charity, migrant food security, social capital, } \\
\text { storm water mitigation, soil remediation }\end{array}$ \\
\hline \multicolumn{3}{|l|}{ Interviewee } \\
\hline \multirow{2}{*}{ Role and Gender } & Female & $5(33 \%)$ \\
\hline & Farmer-Owner & $13(87 \%)$ \\
\hline \multirow{3}{*}{ Status } & High education & $11(73 \%)$ \\
\hline & Mid-career & $8(53 \%)$ \\
\hline & Late-career & $5(33 \%)$ \\
\hline Origin & Immigrant & $5(33 \%)$ \\
\hline Family farm history & $2+$ Generations in farming & $8(53 \%)$ \\
\hline
\end{tabular}

\subsection{Social Networks and Resources}

The starting point for this research was the characterization of urban agriculture as embedded in the urban economic, social, and ecological system, using urban resources, producing for urban citizens, influenced by urban conditions, and impacting the urban system [6]. Notably, it is not just the geographic location, but the embeddedness in the urban system. By applying the concept of social networks to understand how commercial farmers gain access to and make use of tangible and 
intangible assets available to them in the urban context, I found three patterns: farms located in the urban context and embedded in the urban system $(n=7 ; 47 \%)$, farms located in the urban context and embedded in both the local and global system $(n=2 ; 13 \%)$, and farms located outside the urban boundary but embedded in the urban system $(n=4 ; 27 \%)$. Two additional cases $(13 \%)$ of urban food system agents are described.

\subsubsection{Urban Location, Urban System}

Seven farms ( $47 \%$ ) were located within the city boundary (one urban and six peri-urban) that were tied to the urban system through multiple social networks. The urban farm was a social enterprise located in a public park and managed by a city government agency. Functioning as a demonstration farm, at the time of this research the urban farm was not yet economically self-supporting; however, there was a plan to convert a nearby historic building into a farmers' market for selling produce. Strong social ties with local community residents were developed through community outreach and education activities, but weak ties to park users also caused barriers to the operation of the farm, specifically due to park users stealing high-value plants. The plan for opening a farmers' market has the potential to strengthen social networks with other urban farmers, but it is a future initiative.

For the six peri-urban farms, the critical social network was the family-all farms were family-run. Five were multi-generational operations run by migrants or first-generation citizens from diverse countries of origin. The sixth farm was run by an Australian couple who left corporate jobs to start a small family farm. All were located on the western peri-urban edge of Sydney. In all cases, the families participated in farming activities and selling at farmers' markets. Three farms also employed both seasonal and full-time laborers hired through word of mouth. Having strong social ties with other farmers, neighbors, and/or the migrant community provided access to cheap labor (in one case from overseas); however, with the caveat that the farmer would provide a good working environment: "You have to consider how much you pay someone and how much they can do ... Farming is very rough, is about cost, how much is the person working, etc. It is a different mindset here. We do what we can. We live work and eat together. We can't provide the highest wage, but we provide a good working environment-we enjoy each other like a family kind of thing" (SYD11, 52-acre organic vegetable farm).

Social relations with other farmers varied from strong to weak. One farmer said that farmers all talk to each other and talk about common issues such as water problems. Another farmer said that farmers were not helpful at all because they were competitive. A third farmer said that farmers are segregated by race-they communicate, but only within networks of shared culture and language, further explaining that famers do not want to share their secrets. Conversely, a self-starter farmer/cheesemaker said that they were well connected to other farmers-but outside the local farm community, traveling to and being visited by cheesemakers all over the world.

After harvest or when the product was ready (one farm raised dairy animals and produced cheese), it was either taken by one of the farmers to a Sydney farmers' market or sold to a wholesale market. One farm also sold some produce online and another also sold directly to restaurants. Some farms earned the majority of income through Sydney farmers' markets and some farms relied on wholesale for income, but also preferred to participate in Sydney farmers' markets. The point of contact with customers at the farmers' market was crucial for establishing and maintaining strong social ties with consumers. Every farmer spoke enthusiastically about talking to customers: "We have a lot of the same customers coming for many, many years. Look, we have customers come up to the farm. We've got some really good friends that have been our customers over the years" (SYD14, farmer/cheesemaker).

Four farms were located on land facing development pressure-leasing land that was or could be planned for future development. None of the farmers had any connection with government agencies to influence land use and zoning. The two other peri-urban farmers were landowners with more control over the permanence of their operations; however, neither was interested in political discussions with government agencies. One farmer, the adult daughter of the farming family, said her mother had ties 
to local council members because of the mother's past occupation as a medical professional, but they owned their land so there was not any need to reach out.

\subsubsection{Urban Location, Global System}

Two farms (13\%) located within the (urban) city boundary were tied to the global market through labor and distribution social networks. Both were large-scale operations farmed by low-skilled migrants and producing a variety of vegetables on government-owned leased land. As migrants, they maintained a strong social network of family members overseas. They were also well-connected to other migrant farmers of similar geographic origin; they said they knew these other farmers and they helped each other. As commercial operations, both farms employed paid labor in the form of migrant workers. Workers originated from the same overseas province and were connected via word of mouth. There was a strong social network for accessing the overseas migrant labor market: "I am from [Chinese province]. The boss is also from [Chinese province]. Now there are three [people working here]. Yes, all from [Chinese province]. Yes, [I know the other farmers]. They are all around here, there are a lot of farms here. Yes, from [Chinese province], people from [another Chinese province] too. I don't know how to do other work, I came from a farm, doing technical work, I don't have much education background, what else can I do?" (SYD04, vegetable farm, hired migrant laborer).

Both farms reported post-harvest produce was collected and transported to Flemington wholesale market for packaging and resale at various markets and grocery stores. Flemington is a 43-hectare wholesaling business operated by Sydney Markets Ltd., which supplies Sydney with fresh fruit and vegetables. Sydney Markets Ltd. is responsible for approximately one-third of the city's fresh fruit and vegetable supply [21]. One farmer said that he occasionally talked to customers at the market about demand for specific vegetables. The second farmer said there was no contact with customers. In both cases, the social tie to distributors was purely economic, limited to financial exchange with no leverage in terms of pricing or feedback on the quality of the vegetables. Although the farmers had weak direct social ties to customers, both said they selected the types of crops to grow based on market demand of local Asian migrants.

Both farms, located on government-owned leased land, faced increasing development pressure. Residential developments surrounded the two locations, and in one case the farmer had been informed the lease would not be renewed. Despite weak social ties with government agencies that could have mediated the leasing disagreement, the surrounding community protested through social media to protect the land as an agrarian cultural asset-the farm provided natural capital to the community in the form of ecosystem services and beautification. The farm effectively leveraged strong indirect social ties with the surrounding community as a long-term tenant and conservationist of the landscape (providing natural capital), and the government conceded and renewed the lease.

\subsubsection{Rural Location, Urban System}

Four farms (27\%) located outside the urban boundary of Sydney (i.e., rural) were tied to the urban system through multiple social networks. They were large scale operations farmed by multi-generational Australian families, growing a range of standard to specialized vegetables and fruits, with one dairy farm. All were university educated with the youngest generation also employed in professional or service sector jobs. Due to the family farming history, all had strong social networks with other farmers, bearing witness to the decades' struggle for family farms to sustain economic viability. Contradictorily, despite strong bonds with neighbor farmers, there was an aversion to "accessing resources when needed": "Mental health associated with farm work is bad. Get a suicide every now and then. No water in the rivers. No water and too much money spent. [I've] offered [my] own workers because another farmer's worker broke her arm. Us farmers don't ask for help" (SYD05, dairy farm).

The farms ranged from 15 acres to 320 acres, requiring different labor strategies. Two farmers specifically talked about hiring local people, preferring employees with ties to the local community, which translated to long-term commitment. One farmer specifically mentioned hiring differently abled 
workers as well as having a bonfire for employees and families. In all cases, after harvest or when the product was ready for sale, it went to Sydney farmers' markets or to other Sydney buyers. The farm growing specialty vegetables primarily sold directly to Sydney restaurants-generating $80 \%$ of profit through farm to table. The farmer received high accolades for produce quality. Another farm sold direct to cafes and small shops-also generating $80 \%$ of farm income through that market. A third farm sold exclusively at Sydney farmers' markets, and the fourth sold at Sydney farmers' markets plus distributors who exported overseas (the majority of income derive from the latter). In all cases, the farmers cultivated strong social relations with consumers even if by indirect means, e.g., donating products for charity, offering educational farm visits, through agritourism, and on-farm cooking classes.

The social tie with customers extended beyond financial profitability. One farmer explained his view: "People don't like going to supermarket and grocery stores because it misses the connectivity with people. My experience with the community is positive ... If some people can't afford the product they can't afford it. I have a few customers who are very hard up and I give them stuff, and I know who they are. Some of my customers insist on always paying for some. I know I'm doing a good thing. When I have leftover, I donate it. There are many missions looking after homeless people, I take the produce to them. There is one [organization] that comes to [the farmer's market] to collect stuff. They come and ask if anyone has anything to giveaway. [It] closes the loop and keeps the freshness of the produce going" (SYD12, vegetable farm).

All farms were privately owned and at low risk of peri-urban development. However, as rising land values ripple closer, and the next generation loses interest in taking care of the farm, there is always the issue of a farm being sold for retirement and losing another local food producer. When asked about this issue and whether they had any political social networks, there was some sentiment that the government was focused on big business. One farmer stated he was an "influencer" of his local (rural) government, but that did not extend to Sydney agencies. The farmer located furthest from Sydney, a 250-acre vegetable and fruit farm, commented that he was interested in strengthening his social ties to the export market-this was despite selling at three weekly Sydney markets.

\subsubsection{Value-Added and System Complexity}

Two participants (13\%) were not directly involved in farming activities. They were included in the interview sample because of their unique positions in the urban food system: one influencing the production stage and one influencing the processing stage. Both were operations located in commercial buildings in industrial estates in urban Sydney. To protect confidentiality, findings are reported in generic terms. The first participant focused on the ecological viability of urban farming, specifically pollinators-to meet local demand for local produce, there has to be a local supply, and that is difficult without pollinators. The small non-family business provided supplies, education, and maintenance to local growers. The second participant focused on disrupting long supply-chains. The participant explained the brainstorming process: "[My wife and I] go, like, we are a [names specific agricultural product] nation and we only consume $10 \%$ of what we produce and $90 \%$ of what we produce goes out. I have a marketing background and we are taught that marketing is answering a question or solving a problem. Why would they import [this product] in these top restaurants [when we can source and produce it here]? It led to many questions. The answer was [that the] Australian [product] [at the time] tastes like salted water. We don't have a heritage of artisan or cottage industry of making [value-added product]. Why isn't anyone doing it? Why don't we do it?" (SYD13).

Both participants described strong social networks with their respective local growers. One noted a weekly family dinner with one of the producers. However, the degree of influence was different in each case due to where in the process the business was situated in the food system: the pollinator business was in a position to influence farm conditions as a supplier of a necessary input, whereas the business creating a value-added product was in a position to negotiate sales as a customer, and redirect potential overseas sales back to the local market. However, in the latter case, the participant actually gave more influence back to the farmer through marketing of the value-added product by 
promoting the source: they publish flyers to let customers know which farms they source from, and every batch had a sticker to let people know which farm ingredients came from.

\section{Discussion}

\subsection{Urban Food Systems Perspective}

The urban food system, comprised of the different modes of provisioning within a geographic footprint, dependent on resources and cultural conditions [2], is a complex and dynamic system, which makes it difficult to identify underlying mechanisms driving the sustainability and future food security of our cities [3]. Production and supply is an essential point of origin for the functioning of the food system; however, it is increasingly shifting toward global markets. Sydney has a rich agrarian history, but as the city sprawls and pushes the peri-urban fringe further away, local producers dwindle at a time when more people require food (and demand for local is trending up [24]). In this research, the Sustainable Livelihoods Framework was used to conceptualize the commercial urban farmer, representing the producer, as embedded within urban economic, social, and ecological systems in order to shed light on the sustainability and resiliency of the urban food system in Sydney. This paper contributes empirical research on urban farmers' access to resources through social networks. Although three patterns emerged of urban to rural location and accessing local to overseas resources, the dichotomization of urban/rural and local/global are somewhat of a straw man. The overall finding was that farmers accessed resources in a variety of ways in an effort to sustain their agrarian livelihoods-building and maintaining relationships across their social networks to meet requirements aligned with the farmers' culture and preferences. Based on findings, three points warrant discussion.

First, farmers highlighted the importance of the connection to the customer through non-financial transactions. Findings complement and add depth to studies exploring non-economic and sharing/moral economy aspects to farmers' market interactions [41-43]. The direct relationship between producer and consumer enables immediate feedback and modification of what was sold and what was purchased. Specifically, in this study, the direct interaction with customers at farmers' markets was an important social relationship even, and especially, for farms that only profited a small percentage of overall income from farmers' markets. Farmers offered customers suggestions on how to prepare or cook the produce/product, shared updates about farm animals, filled orders as a courtesy while customers shopped around at other stalls, delivered orders for no charge to regular customers if they could not make it to the market on a particular day, and generally chitchatted. Customers offered feedback, which many interviewed farmers stressed as invaluable and not easily replicated through formal marketing surveys. Customers also asked questions about the farms, such as how the product was grown/raised. One farmer said it succinctly: "People want more than just vegetables" (SYD12, vegetable farm). Farming was not just a job for interviewees-it was a way of living.

As a "way of living", farming was a livelihood embraced because of family tradition and/or a strong valuing of high-quality, locally produced food, grown in a way to protect natural ecosystems, promote equitable access to fresh food, and perpetuate artisan practices. Repeatedly, farmers noted that income was only one aspect: “It's economically viable. It isn't hugely financially rewarding, but it is a labour of love" (SYD12, vegetable farm). Another said: "You never put a dollar plus on the hours of work that we put into, you just, you cry if you realize how much you're actually earning an hour, you're thinking what on earth were you doing?" (SYD14, animal husbandry). Another stated: "In Australia they released which income earns the most money and farmers earn $\$ 22 \mathrm{k}$ a year. It is incentive to sell a farm. It isn't an incentive to be a farmer. If you are not born into farming it is difficult" (SYD15, vegetable farm). This points to the importance of the family as a critical social tie and how difficult it is to replace farms once they close. The adult daughter of a vegetable farmer said, "I admire the 1-acre hippies from the city who chose to get into farming. It is very brave of them and for them to go into something like this if your family isn't in it. If you don't do it for a while, it takes a while to like it. Even if you get into farming, it might take a while to like it. I am always amazed and intrigued for 
those who tried to do it and try to learn everything and they didn't even grow up with it. The farming side, the paperwork, the pipes. I don't know how people do it by themselves"' (SYD11, vegetable farm). There are few studies on urban farmers' motivations; however, a recent study by Kopiyawattage et al., using the Theory of Planned Behavior, found the support of family and friends as a critical motivation to continue farming in an urban context [44]. The authors highlighted that factors influencing farmers' behaviors is under-researched-an important area for investigation in light of the urgency to feed urban populations.

A third important finding was the social ties with other farmers-and those claiming to be commercial farmers. Farmer-to-farmer ties were found to be a contested network, which requires more investigation to better understand how farmers help and hinder each other. In general, farmers talked to each other and gave advice. Farmers' markets were an important point of contact for some farmers who might not regularly see other farmers due to the time needed to operate their farm. There was also some mention of farmer associations as a knowledge resource for policies, tax levies, and regulations. However, some of the interviewed farmers, from a specific migrant community, said that farmers did not help each other, but were only in it for themselves-ties were based on competition. A similar theme related to issues of dishonesty. One farmer said that some sellers at the farmers' market claimed to be the farmer but were only distributors (unsolicited, the farmer mentioned two farmers who participated in this study; I was unable to verify the claim). More investigation is needed into how farmers handle conflict. There was also mention that some stalls advertised organic produce when it was not, claimed to sell a local brand when it was not, and generally detracted from the overall positive social network of farmers participating in the farmers' markets. Negative in addition to positive social networks among famers is an under-research area that is only emerging now in the developing or rural context [45-47].

A final note about negative social ties: one farmer relayed an experience with a local restaurant, "I' $m$ the only local [product] producer, and I can tell you the amount of restaurants that I supply. [I had] people coming in and saying, 'We went to a restaurant this weekend and we had your [product].' I go, 'Which restaurant was that?' and I supply them all, we don't have a distributor so I know exactly where my [products] go and I know how much that's going there. I go, 'No, it's not my [product].' I'll ring the restaurant and I'll say 'Whose cheese you've got on there?' and they'll say [name of farm] and I'll go, 'Well you better get it off your menu cause I'm not supplying you.' They don't buy it from anywhere, they just use your name because you're a local producer" (SYD14, farmer/cheesemaker). The issue of authenticity, cited in the literature in the context of farmers' markets, is an agreement between farmers and consumers that products sold should be locally produced by the seller-however, there is some indication that customers acknowledge and accept that not everything will be local nor will it be produced by the seller [48,49]. Local food systems are highly dependent on public trust, which can easily be eroded, but difficult to gain back; however, customers seem to be more tolerant in their expectations than farmers assume.

\subsection{Implications and Areas for Future Study}

There is an argument for land use policies that preserve Sydney's surrounding farmlands, but land protection is a simplistic strategy for two reasons: first, farms who plan to eventually sell (because the younger generation is not interested in farming) will lose out on a potential retirement income from rising land values, and second, land is only one driver, among many, of the sustainability of the local food system. At this stage of urbanization, protection of land might not be sufficient to secure enough land to produce a significant contribution of fresh product for the city [21]. Furthermore, a new plan for integrating residential and agricultural land uses (i.e., Horsley Park Masterplan) is controversial: "A lot of development was going on in the outer west of Sydney and we were looking at actually starting up a whole ... a different farm on the government land and it would've been like an educational school, but the red tape, I was like I can't do it ... I've looked at that a little bit. I've heard some feedback from other farmers too, not positive" (SYD14, farmer/cheesemaker). So what other 
components of the urban food system could be leveraged? The pathways are multiple and only a few will be suggest here based on interview findings.

In addition to farmers' markets, pop-up markets could be a flexible approach for farmers and local distributors to target more areas. One farmer talked about testing this out: "I've set up a space in an alleyway in the western suburb, and that is doing well at the moment ... I think there is opportunity to have local community farm to city where people are getting good fresh produce and have the opportunity to consume it here. I know I will need to get a collection or curation and bring it together. Would love to do pop up locations" (SYD12, vegetable farm). Pop-up markets enable farmers to tap into communities in a less formal way and bring in new customers-people just passing by. It could enable consumers who do not typically go to farmers' markets to connect with local producers.

Another opportunity relates to social media education and training. About half the farmers interviewed maintained active Instagram accounts-fewer were on Facebook. Websites are not interaction, whereas social media keeps the social tie with customers alive outside the market. However, not every farmer is tech savvy: "Unfortunately we could be in a different situation than we are now if I was up to social media, and that's one thing I just find that if I could say to somebody that was gonna go to a [food processing] course or social media course, I'd say the social media course, every time, because you can work at a [food processing] thing but unless you're on top of all that social media, you can forget it, they're making and breaking you out there" (SYD14, farmer/cheesemaker).

Because of the high barriers to entry into local food production, incubation of ideas is critical for both potential producers as well as value-added businesses. The interview with the value-added business disrupting long supply-chains said: “Now we just qualified for the government's growth plan. We consulted for 2 years, that guides us in writing up a growth plan for our business ( $3-5$ years). It's all about our government wants us to export more. They focus on companies that are doing really well and having positive growth. They want you to do even better and they will help you do even better" (SYD13). This points to the complexity of the system: a local business using a typically exported local product, processing it as a local value-added product, and finally expanding into the global market due to success. The business intends to market both locally and globally. It is important to also note that not all farmers were focused on expansion-actually, many were at, or close to, the size or scale they wanted to maintain. This links back to motivation to have an agrarian livelihood and the connection to the consumer: "There are some companies that do what I do but they do it at a large scale, but it isn't personal" (SYD12, vegetable farm).

\subsection{Limitations}

A notable limitation of this research was the small sample size. Due to the limited time to conduct interviews, about half of invited farms were not interviewed. With the variety of farms in and around Sydney, from mushroom growers to orchards, it is possible more variations of social networks would have been captured. Validity of findings in this study was improved by seeking farmers with diverse backgrounds and producing diverse products. An important strength of this research was the rich qualitative data collected through in-person interviews. Most farmers were patient and gave thoughtful, narrative responses. A structured or paper/online survey would not have captured the emotional connections expressed by interviewees when describing various interactions with other farmers, customers, even local politicians. While the survey questions were carefully constructed using the Sustainable Livelihoods Framework and social network theory, I acknowledge potential issues of construct validity in operationalizing complex concepts. A potential source of bias related to the key finding in this research of the positive tie to customers also needs mentioning. Because farmers' markets were used as the sampling frame to generate the population list of local producers' link to the urban market, it makes sense that farmers expressed a strong connection with their customers at farmers' markets. This research did, however, uncover nuanced social ties with customers beyond simple financial gain that adds complexity to understanding the relationship. 


\section{Conclusions}

The urban food system is dynamic and complex, driven by multiple and often competing actors and processes. This paper contributes empirical qualitative research on commercial urban farmers' access to resources through social networks in the context of Sydney, Australia. Although the focus was on one type of urban agriculture, it contributes descriptive examples of potential drivers and constraints for sustaining and implementing different types of urban agriculture for a more resilient urban food system. Specifically, key drivers for pursuing an agrarian livelihood in the context of Sydney were the supportive network of farmers, family tradition of farming, and personal relationship with consumers. Farmer networks were also a source of constraint within certain migrant communities, where there was also some distancing from consumers due to a longer distribution chains. With increasing pressures on peri-urban agricultural land for affordable housing, and increased competition from cheap imported food, understanding how local food producers are leveraging social networks to be part of the local food system in a way that is sustainable economically, and in a way that provides a meaningful livelihood, can inspire city governments to develop more creative strategies for planning a sustainable food system. Finally, aligned with the research design of this study to situate urban producers within a comprehensive food system, food hubs offer a promising and holistic way forward [50].

Funding: This research was funded by the Singapore Ministry of Education (MOE) Start-up Grant for New Faculty, funding \# R-295-000-141-133.

Acknowledgments: Ching Sia Sian, PhD candidate in Architecture, for research assistance conducting interviews and Bao Lixia, Master of Landscape Architecture student, for research assistance coding interviews. Both affiliated with the National University of Singapore. A special acknowledgement to the farmers and key stakeholders who volunteered precious time to share personal experiences in participating in this study. Their role in the local Sydney food system is invaluable.

Conflicts of Interest: The author declares no conflict of interest. The funders had no role in the design of the study; in the collection, analyses, or interpretation of data; in the writing of the manuscript, or in the decision to publish the results.

\section{References}

1. Zeeuw, D.H.; Dreschel, H. Cities and Agriculture. Developing Resilient Urban Food Systems; Routledge: Abington, UK, 2015.

2. Wiskerke, J.S. Urban Food Systems, in Cities and Agriculture; de Zeeuw, H., Drechsel, P., Eds.; Routledge: Abington, UK, 2015; pp. 19-43.

3. Béné, C.; Prager, S.D.; Achicanoy, H.A.; Toro, P.A.; LaMotte, L.; Cedrez, C.B.; Mapes, B. Understanding food systems drivers: A critical review of the literature. Glob. Food Secur. 2019, 23, 149-159. [CrossRef]

4. Kasper, C.; Brandt, J.; Lindschulte, K.; Giseke, U. The urban food system approach: Thinking in spatialized systems. Agroecol. Sustain. Food Syst. 2017, 41, 1009-1025. [CrossRef]

5. Bryld, E. Potentials, problems, and policy implications for urban agriculture in developing countries. Agric. Hum. Values 2003, 20, 79-86. [CrossRef]

6. van Veenhizen, R. (Ed.) Cities Farming for the Future: Urban Agriculture for Green and Productive Cities; Foundation, IDRC and International Institute for Rural Reconstruction: Leusden, The Netherlands, 2006.

7. Mougeot, L.J.A. Urban Agriculture: Definiton, Presence, Potentials and Risks. Growing Cities, Growing Food: Urban Agriculture on the Policy Agenda; International Development Research Centre (IDRC): Ottawa, ON, Canada, 2000; pp. 1-42.

8. Lonard, C.S. Urban Fringe Agriculture and Its Potential Contribution to Sustainable Cities: A Case Study of Western Sydney; University of Southern Queensland: Darling Heights, Australia, 2012.

9. Scoones, I. Livelihoods perspectives and rural development. J. Peasant. Stud. 2009, 36, 171-196. [CrossRef]

10. Scoones, I. Sustainable Rural Livelihoods: A Framework for Analysis, in IDS Working Paper 72; IDS: Brighton, UK, 1998.

11. Carney, D. Sustainable Livelihoods Approaches: Progress and Possibilities for Change; Department for International Development London: London, UK, 2003. 
12. Birkmann, J. (Ed.) Measuring vulnerability to promote disaster-resilient societies: Conceptual frameworks and definitions. In Measuring Vulnerability to Natural Hazards; United Nations University Press: New York, NY, USA, 2006.

13. De Haan, L. The livelihood approach: A critical exploration. Erdkd. 2012, 66, 345-357. [CrossRef]

14. Groenewald, S.F.; Bulte, E. Trust and livelihood adaptation: Evidence from rural Mexico. Agric. Hum. Values 2012, 30, 41-55. [CrossRef]

15. Parizeau, K. When Assets are Vulnerabilities: An Assessment of Informal Recyclers' Livelihood Strategies in Buenos Aires, Argentina. World Dev. 2015, 67, 161-173. [CrossRef]

16. Blaikie, P.; Cannon, T.; Davis, I.; Wisner, B. At Risk: Natural Hazards, People's Vulnerability and Disasters; Routledge: New York, NY, USA, 1994.

17. Knoke, D.; Yang, S. Social Network Analysis, 2nd ed.; Quantitative Applications in the Social Sciences; SAGE Publications: Los Angeles, CA, USA, 2008.

18. Pappi, F.U.; Scott, J. Social Network Analysis: A Handbook. Contemp. Sociol. A J. Rev. 1993, $22,128$. [CrossRef]

19. Merson, J.; Attwater, R.; Ampt, P.; Wildman, H.; Chapple, R. The challenges to urban agriculture in the Sydney basin and lower Blue Mountains region of Australia. Int. J. Agric. Sustain. 2010, 8, 72-85. [CrossRef]

20. United Nations Department of Economic and Social Affairs Population Division. The World's Cities in 2018. Data Booklet; United Nations: New York, NY, USA, 2018.

21. O'Neill, P.; James, S. Feeding Sydney: Assessing the Importance of the City's Peri-urban Farms. Ecol. Transp. 2014, 71, 243-256. [CrossRef]

22. James, S. (Ed.) Growing Sydney, in Farming on the Fringe: Peri-Urban Agriculture, Cultural Diversity and Sustainability in Sydney; Springer International Publishing: Cham, Switzerland, 2016; pp. 27-61.

23. James, S. Farming on the Fringe; Springer Science and Business Media LLC.: Berlin/Heidelberg, Germany, 2016.

24. Mason, D.; Knowd, I. The emergence of urban agriculture: Sydney, Australia. Int. J. Agric. Sustain. 2010, 8 , 62-71. [CrossRef]

25. McFarland, P. Multi-functionality and the Urban-Rural Dichotomy in Australian Metropolitan Planning. In State of Australian Cities Conference 2015: Refereed Proceedings; Griffith University: Nathan, Australia, 2015.

26. McFarland, P. The Peri-urban Land-Use Planning Tangle: An Australian Perspective. Int. Plan. Stud. 2014, 20, 161-179. [CrossRef]

27. Schensul, J.; LeCompte, M. Designing and Conducting Ethnographic Research; Altamira Press: Walnut Creek, CA, USA, 1999; Volume 1.

28. Trotter, T.R.; Schensul, J.J. Methods in Applied Anthropology. Handbook of Methods in Cultural Anthropology. HR Bernard; AltaMira Press: Walnut Creek, CA, USA, 1998.

29. Guest, G.; Bunce, A.; Johnson, L. How many interviews are enough? An experiment with data saturation and variability. Field Methods 2006, 18, 59-82. [CrossRef]

30. Diehl, J.A.; Bose, M.; Main, D.S. A Social and Spatial Network Approach to Understanding Beliefs and Behaviors of Farmers Facing Land Development in Delhi, India. In Cities as Spatial and Social Networks; Springer Science and Business Media LLC.: Berlin/Heidelberg, Germany, 2018; pp. 73-99.

31. Diehl, J.A.; Oviatt, K. Productive Urban Landscapes: Emerging Hybrid Typologies of Form and Function; Walter de Gruyter GmbH: Berlin, Germany, 2019; pp. 227-243.

32. Crooks, A.; Pfoser, D.; Jenkins, A.; Croitoru, A.; Stefanidis, A.; Smith, D.; Karagiorgou, S.; Efentakis, A.; Lamprianidis, G. Crowdsourcing urban form and function. Int. J. Geogr. Inf. Sci. 2015, 29, 720-741. [CrossRef]

33. Dubbeling, M. Optimizing Use of Vacant Space for Urban Agriculture through Participatory Planning Processes: A Strategy to Strengthen Urban Food Security and Municipal Participatory Governance; Technical Progress Report, May 2002-June 2003; IDRC: Ottawa, ON, Canada, 2003.

34. Drescher, A. Food for The Cities: Urban Agriculture in Developing Countries. Acta Hortic. 2004, $227-231$. [CrossRef]

35. Mubvami, T.; Mushamba, S. Integration of agriculture in urban use planning. In Cities Farming for the Future; Urban Agriculture for Green and Productive Cities; IDRC: Ottawa, ON, Canada, 2006; pp. 54-74.

36. Nugent, R. The impact of urban agriculture on the household and local economies. In Growing Cities, Growing Food: Urban Agriculture on the Policy Agenda; ZEL: Feldafing, Germany, 2000; pp. 67-97.

37. Philips, A. Designing Urban Agriculture: A Complete Guide to the Planning, Design, Construction, Maintenance and Management of Edible Landscapes; John Wiley \& Sons: Hoboken, NJ, USA, 2013. 
38. Smit, J.; Bailkey, M.; Van Veenhuizen, R. Urban Agriculture and the Building of Communities. In Cities Farming for the Future, Urban Agriculture for Green and Productive Cities; Van Veenhuizen, R., Ed.; RUAF Foundation: Leusden, The Netherlands, 2006; pp. 146-171.

39. Waters-Bayer, A. Living with livestock in town. Urban Agric. Mag. 2000, 1, 16-18.

40. Lin, N. Building a network theory of social capital. In Social Capital: Theory and Research; Lin, N., Cook, K., Burt, R.S., Eds.; Aldine De Gruyter: New York, NY, USA, 2001; pp. 3-29.

41. Crawford, B.; Byun, R.; Mitchell, E.; Thompson, S.; Jalaludin, B.; Torvaldsen, S.; Torvadsen, S. Seeking fresh food and supporting local producers: Perceptions and motivations of farmers' market customers. Aust. Plan. 2018, 55, 1-8. [CrossRef]

42. Carson, R.A.; Hamel, Z.; Giarrocco, K.; Baylor, R.; Mathews, L.G. Buying in: The influence of interactions at farmers' markets. Agric. Hum. Values 2015, 33, 861-875. [CrossRef]

43. Leiper, C.; Clarke-Sather, A. Co-creating an alternative: The moral economy of participating in farmers' markets. Local Environ. 2017, 22, 840-858. [CrossRef]

44. Kopiyawattage, K.P.; Warner, L.; Roberts, T.G. Understanding Urban Food Producers' Intention to Continue Farming in Urban Settings. Urban Agric. Reg. Food Syst. 2019, 4, 1-11. [CrossRef]

45. Sutherland, L.-A.; Burton, R.J. Good Farmers, Good Neighbours? The Role of Cultural Capital in Social Capital Development in a Scottish Farming Community. Sociol. Rural 2011, 51, 238-255. [CrossRef]

46. Méndez-Lemus, Y.; Vieyra, A. How social capital enables or restricts the livelihoods of poor peri-urban farmers in Mexico. Dev. Pract. 2017, 27, 301-315. [CrossRef]

47. Nygren, A.; Myatt-Hirvonen, O. 'Life here is just scraping by': Livelihood strategies and social networks among peasant households in Honduras. J. Peasant. Stud. 2009, 36, 827-854. [CrossRef]

48. Smithers, J.; Joseph, A.E. The trouble with authenticity: Separating ideology from practice at the farmers' market. Agric. Hum. Values 2009, 27, 239-247. [CrossRef]

49. E Joseph, A.; Chalmers, L.; Smithers, J. Contested and congested spaces: Exploring authenticity in New Zealand farmers' markets. N. Z. Geogr. 2013, 69, 52-62. [CrossRef]

50. Berti, G.; Mulligan, C. Competitiveness of Small Farms and Innovative Food Supply Chains: The Role of Food Hubs in Creating Sustainable Regional and Local Food Systems. Sustainability 2016, 8, 616. [CrossRef]

(C) 2020 by the author. Licensee MDPI, Basel, Switzerland. This article is an open access article distributed under the terms and conditions of the Creative Commons Attribution (CC BY) license (http://creativecommons.org/licenses/by/4.0/). 